\title{
Introduction: Friends and Family Figures in Contemporary Fiction
}

\author{
KATHARINE COCKIN \\ (Guest Editor)
}

During the twentieth century, scientific advances, especially in the field of reproductive technologies, have fundamentally altered ideas about parenting, the family and what it means to be human. In the 1980 s, the family became a significant site of political conflict in the UK when family values were defended and so-called pretended families were condemned. New information technologies make it possible for online chat between friends who have never met. Changes in legislation have defined and protected the rights of the child and spectacular campaigns have developed for fathers' rights. Meanwhile tracing your family history has become one of the most popular hobbies.

Some of these issues are the primary concern of the articles collected here, which developed from papers given at the conference on the theme, 'Near and Dear, Gender, Generation and Genealogy: Friends and Family Figures in Contemporary Fiction' held at the University of Hull in May 2005. Estella Tincknell, who has recently worked on the impact of the nuclear family on cultural representations and social policy in the second half of the twentieth century, focuses here on the tensions between marriage and career in the novels of Barbara Pym, with particular reference to Jane and Prudence (1953). If the family has ever functioned as a social and ideological fulcrum, the profound strains of modern living have knocked it off-balance. In contemporary fiction later in the twentieth century, these conflicts have demonstrable effects on the understanding of intimate relationships. The literary effect of challenging the patriarchal force of the family as an institution is drastic and the tremors are visible at the level of narrative structure. Carol Cadwalladr's novel The Family Tree, for instance, is driven by a search. In the epigraphs a dislocated lexicographical trail pursues 
possible definitions of the family. Several of the texts discussed here, including Ahdaf Soueif's Map of Love (1999), are organised along apparently chronological or sequential lines only to be disrupted by parallel narratives, oscillations between present and past, as characters urgently seek truths from family histories.

In Behind the Scenes at the Museum (1995), a chronological framework of sequentially numbered chapters is interpolated by an explanatory narrative of footnotes. Sinead McDermott attends to the complexity of Kate Atkinson's ambitious and ultimately optimistic mapping of changing family relationships in this novel. Beginning with an impossibly omniscient foetal narrator, these relationships are opened up, actually and virtually through memory and fantasy, and actually across several generations, as they extend geographically across the world. While the painful and destructively tragic impact of the family romance is scrutinised in an analysis which exposes 'the potential monstrosity of the family' (76), McDermott's attention to the historical location of the family is especially illuminating. The gruesome fascination with the magnetic, often destructive forces at work within the family, provides an unexpected point of connection between Kate Atkinson and Jeanette Winterson. In Julie Ellam's article, Winterson's preoccupation with family figures and the nurturing of children appears simultaneously to defamiliarise the family and to anchor itself conservatively in the bonds of love. While family bonds are based on contiguity, individual identity is presumed to be unique. The clone shatters these fundamental beliefs. The disruptive and transformative potential of scientific developments, in particular reproductive technologies, are evident in Zoë Brigley's analysis of the clone in Deryn Rhys-Jones' Quiver (2004), a series of poems designed to be read as a complete narrative.

Katharine Cox maps out the apparently unchartable, often baffling complexities of Danielewski's House of Leaves (2000). Thus the fraught representation of the mother-son relationship is mediated through the use of the labyrinth, and the related spatial and architectural metaphors decentre the home and problematise the quest for origins of any kind. Journeys in search of lost relatives and fragmented narratives concern Ahdaf Soueif's Map of Love (1999). Catherine Wynne analyses Soueif's treatment of meeting grounds and hybridity in the family mediated through the construction and discovery of the narratives of female travellers. In his analysis of Andrea Levy's Small Island (2004), Caryl Phillips' Crossing the River 
(1993) and Buchi Emecheta's The New Tribe (2000), John McLeod uses Edward Said's notion of affiliative rather than filiative relationships to explore the figure of adoption in these postcolonial fictions. This provides a fascinating insight into the conflicting associations of adoption with the institutionally regulated formation of a family and with the sense of freely chosen primary relationships. The new research presented here demonstrates that contemporary fiction is responding to the increasingly permeable boundaries of the family structure, the ascendancy of friend over family member and the reassessments of those we hold nearest and dearest. 